\title{
BIOETHANOL PRODUCTION BY CALCIUM ALGINATE-IMMOBILISED ST1 YEAST SYSTEM: EFFECTS OF SIZE OF BEADS, RATIO AND CONCENTRATION
}

\author{
M. M. ZAIN, N. T. Kofli AND S. R. S. YAHYA \\ Department of Chemical and Process Engineering \\ Faculty of Engineering and Built Environment, \\ Universiti Kebangsaan Malaysia, 43600 Bangi, Selangor, Malaysia. \\ masni.roszaime@gmail.com
}

\begin{abstract}
Immobilized yeast-cell technology posses several advantages in bioethanol production due to its potential to increase the ethanol yield by eliminating unit process used. Thus, process expenses in cell recovery and reutilization can be minimised. The aim of this study is to investigate the influence of three parameters (substrate concentrations, size of alginate beads and ratio of volume of beads to volume of medium) on local isolated yeast (ST1) which immobilized using calcium alginate fermentation system. The most affected ethanol production by calcium alginateimmobilised ST1 yeast system were ratio of volume of the beads to the volume of substrate and concentration of LBS. Highest theoretical yield, 78\% was obtained in ST1alginate beads with the size of beads $0.5 \mathrm{~cm}$, ratio volume of beads to the volume of LBS media 0.4 and $150 \mathrm{~g} / \mathrm{L}$ concentration of LBS.
\end{abstract}

ABSTRAK: Teknologi sel yis pegun memiliki beberapa kelebihan dalam penghasilan bioetanol kerana ia berpotensi meningkatkan pengeluaran etanol dengan menyingkirkan unit proses yang digunakan. Maka, proses pembiayaan dalam perolehan sel dan penggunaan semula boleh dikurangkan. Tujuan kajian ini adalah untuk mengkaji pengaruh tiga parameter (kepekatan substrat, saiz manik alginat dan nisbah isipadu manik terhadap isipadu bahantara) ke atas sel tempatan terasing (local isolated yeast $(S T 1))$ yang dipegun menggunakan sistem penapaian kalsium alginat. Penghasilan etanol yang paling berkesan dengan menggunakan sistem yis ST1 kalsium alginat-pegun adalah dengan kadar nisbah isipadu manik terhadap isipadu substrat dan kepekatan LBS. Kadar hasil teori tertinggi iaitu $78 \%$ didapati menerusi manik alginat-ST1 dengan saiz manik $0.5 \mathrm{~cm}$, nisbah isipadu 0.4 terhadap perantara LBS dan kepekatan LBS sebanyak 150 $\mathrm{g} / \mathrm{L}$.

KEYWORDS: immobilization; bioethanol; calcium alginate

\section{INTRODUCTION}

The production of bioethanol as an alternative fuel by fermentation of sugar has been increasing due the growing demands, which is expected to produce high and good yield of ethanol [1-4]. Isolating and inoculating selected potential yeasts and alternative economic evaluation for ethanol production has become popular topic amongst researchers. Immobilization applied the cells entrapped inside the inert support meanwhile separation of bioethanol from the medium should be easier and cost saving since it is omitting a unit procedure than those of free cells while retaining their desired catalytic activities for repeated and continuous use [5-7] which created possibility for the cells to be reused. 
Calcium alginate matrix entrapment has been approached widely in the immobilization of bacteria, yeast fungi, algae in many different bioprocesses, such as wastewater treatment, vinegar production, and ethanol production due to the simplicity of this method, it is nontoxic, less expensive, reversible, and has good mechanical properties $[6,8,9]$. Sodium alginic is a linear polysaccharide extracted from many strains of brown algae and seaweed and solidification of sodium alginate occur in calcium chloride solution by displacement of sodium ion $[10,11]$.

Most East-Asian countries have their own traditional fermented food and an alcoholic beverage which is produced at household or cottage industry scales [12, 13]. For Malaysia, which consist of multiple races, produced various fermented foods and amongst the popular are tapai and tuak. Tapai is a food made from tapioca (cassava), glutinous rice, rice or banana can be eaten raw after few days of fermentation with ragi. Similar to Indonesian tape ketan (black rice fermentation), Malaysia tapai is partially liquefied, sweet sour and mildly alcoholic rice paste served as dessert or snack. Whereas tuak is rice wine for native peoples (especially in Sarawak) usually serve during special and important occasions. Tuak is prepared similarly like tapai but in longer fermentation period, resulting in greater liquefaction of the rice and consumed as an alcoholic beverage. Since both tapai and tuak production a must of fermented rice, this process is referred as tape fermentation [13-15] but in local language is called tapai fermentation.

There are many reported studies that using manipulating unsterilized juice as a substrate on bioethanol production $[16,17]$. Local brown sugar (LBS), also known as 'gula merah' in Malay is the names of jaggery, a traditional unrefined sugar consumed in Asia, Africa, Latin America and Caribbean $[16,18]$ It is a natural sweetening substance made by concentrating sugarcane juice without any preservatives and colourings.

The ultimate objective of this study is to investigate the influence of three parameters (substrate concentrations, size of alginate beads and ratio of volume of beads to volume of medium) on local isolated yeast (ST1) which immobilized using calcium alginate fermentation system. ST1 strain is isolated from starter ragi from Sarawak which is used in preparation of traditional fermented food, tapai and tuak. Local brown sugar (LBS) is a natural sweetening substance made by concentrating sugarcane juice without any preservatives and colourings. It is normally used in preparing cakes, syrups and desserts and sold cheaply at the local market. The usage of local yeast in production of ethanol has to be explored to enrich the culture collection as well as a novel way in ethanol production.

\section{MATERIALS AND METHODS}

\subsection{Microorganism}

The starter ragi is bought at the local market in Kuching, Sarawak (Malaysia). The starter ragi is dry flattened circular cakes, about $3-5 \mathrm{~cm}$ in diameter, prepared from rice flour and packed in small plastic bag. It was subcultured, screened and isolated on Sabouraud agar [19] to produce a single colony. The strain selected was named as ST1 and was kept on YPD medium/agar at $4^{\circ} \mathrm{C}$.

\subsection{Substrate}

Cheap local brown sugar (LBS) was used as medium. It was bought at the local supermarket in a packed plastic. Preparation of medium followed the method by Bravo and Gonzales [18]. The composition of the medium is LBS (100-200 g/L) which was diluted and filtered with addition of $5.19 \mathrm{~g} / \mathrm{L}\left(\mathrm{NH}_{4}\right)_{2} \mathrm{SO}_{4}, 1.53 \mathrm{~g} / \mathrm{L} \mathrm{KH}_{2} \mathrm{PO}_{4}$ and $0.55 \mathrm{~g} / \mathrm{L}$ 
$\mathrm{MgSO}_{4}$. YPD medium is commercialised medium for yeast consist of : yeast extract 10 $\mathrm{g} / \mathrm{L}$, peptone $20 \mathrm{~g} / \mathrm{L}$ and dextrose $20 \mathrm{~g} / \mathrm{L}$.

\subsection{Cell Immoblisation}

ST1 cells were grown at $30^{\circ} \mathrm{C}$ for 10 hours. $150 \mathrm{ml}$ culture broths were harvested by centrifuge at $13000 \mathrm{rpm}$ for 5 minutes. $50 \mathrm{ml}$ of this growth medium was mixed with an equal volume $(1: 1, \mathrm{v} / \mathrm{v})$ of $4 \%(\mathrm{w} / \mathrm{v})$ Na-alginate (Sigma, A-2033) solution. A $100 \mathrm{ml}$ aliquot of alginate-cell suspension containing $2 \%$ Na-alginate (unless otherwise stated) was added dropwise to $1000 \mathrm{ml}$ of $2 \% \mathrm{CaCl}_{2}$ with a syringe [20]. Alginate drops solidified upon contact with $\mathrm{CaCl}_{2}$, forming beads and thus entrapping yeast cells. The beads were allowed to harden for $30 \mathrm{~min}$ and then were washed with sterile saline solution $(0.85 \%$ $\mathrm{NaCl})$ to remove excess calcium ions and cells.

\subsection{Fermentation}

ST1-alginate beads fermentation was carried out in $250 \mathrm{ml}$ flask supplemented with $150 \mathrm{ml}$ local brown sugar as a media. Three variables parameters were chosen to investigate their affect on bioethanol production performance; size of the alginate-ST1 beads, ratio of the beads to the substrate and concentration of LBS. Two selected size of the beads, $0.3 \mathrm{~cm}$ and $0.5 \mathrm{~cm}$ in diameter were form using different nozzles and kept in $0.2 \%$ Yeast Extract until use. The volume of the beads was measured by cylinder measurement in order to investigate the ratio of volume of beads to volume of substrate. The immobilized yeast was incubated in $30^{\circ} \mathrm{C}$ with agitation at $75 \mathrm{rpm}$ to avoid breakage.

\subsection{Analytical Method}

Ethanol and glucose concentrations were determined using biochemical analyzer, YSI Select (Yellow Spring Ltd.).

\section{RESULTS AND DISCUSSION}

\subsection{Immobilisation}

The most common forms are round small beads about 0.3 to $5 \mathrm{~mm}$ in diameter, and the small diameter beads are generally preferred because of the favourable mass transfer characteristics for the entrapped cells [6] and stability due avoid damage occurs. The effect of bud-like shape of alginate bead on the surface area was not investigated and all beads were assumed to be spheres. At this diameter and alginate concentration used ( $2 \mathrm{wt}$ $\%$ ), the beads were fully active, flexible and hard enough to stand mild agitation and have a good stability [10]. Figure 1 showed the observation by scanning electron microscope for ST1-alginate beads.

\subsection{Effects of Size of Beads}

The effect of alginate-ST1 beads size in LBS fermentation was studied. The beads with diameter $0.3 \mathrm{~cm}$ and $0.5 \mathrm{~cm}$ were prepared by using different nozzles and the fermentation was carried out in $50 \mathrm{~g} / \mathrm{L}$ and $150 \mathrm{~g} / \mathrm{L}$ concentration of LBS and the result is shown in Fig. 2 and 3. The ethanol production curve is identical to both 0.3 and $0.5 \mathrm{~mm}$ beads size and the highest ethanol production $(8.2 \mathrm{~g} / \mathrm{L})$ was obtained with cell entrapped in $0.5 \mathrm{~cm} \mathrm{Ca}$-alginate beads. In fact, immobilization fermentation considered mass transfer phenomena as smaller beads has more surface area available for mass transfer of substrate through the beads $[6,11]$. However, since the beads are rigid, the agitation rate has to be low to prevent the beads breakage but small beads also tend to attach among themselves. 


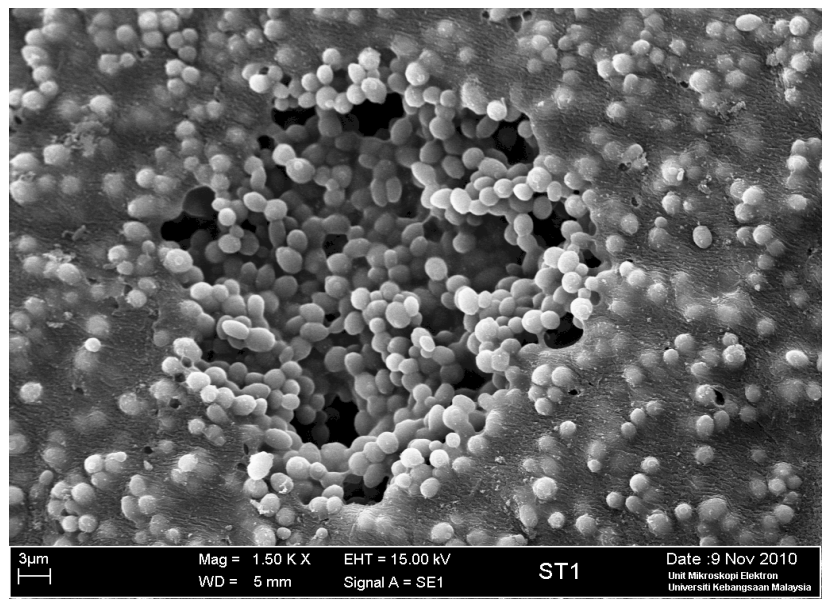

(a)

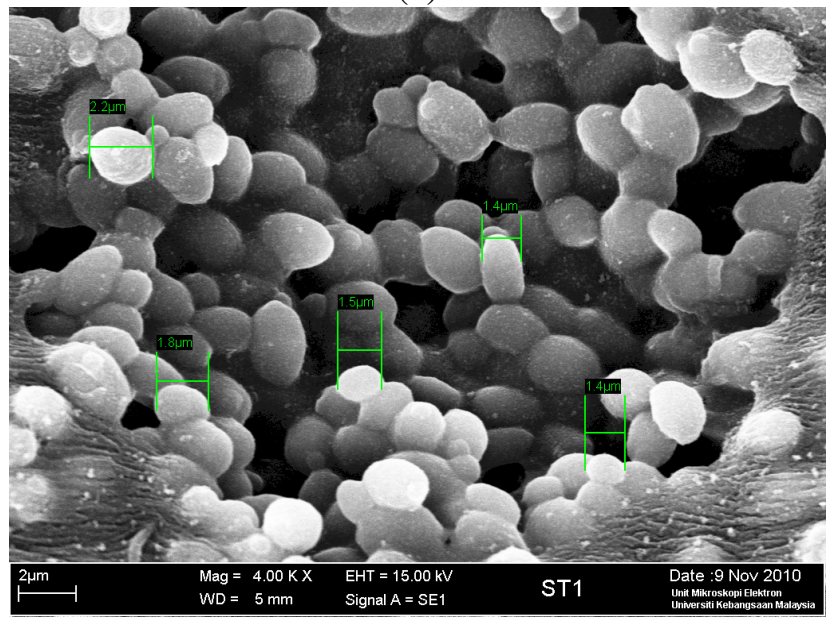

(b)

Fig. 1: Scanning electron microscopy of immobilized yeast cell (a) \& (b).

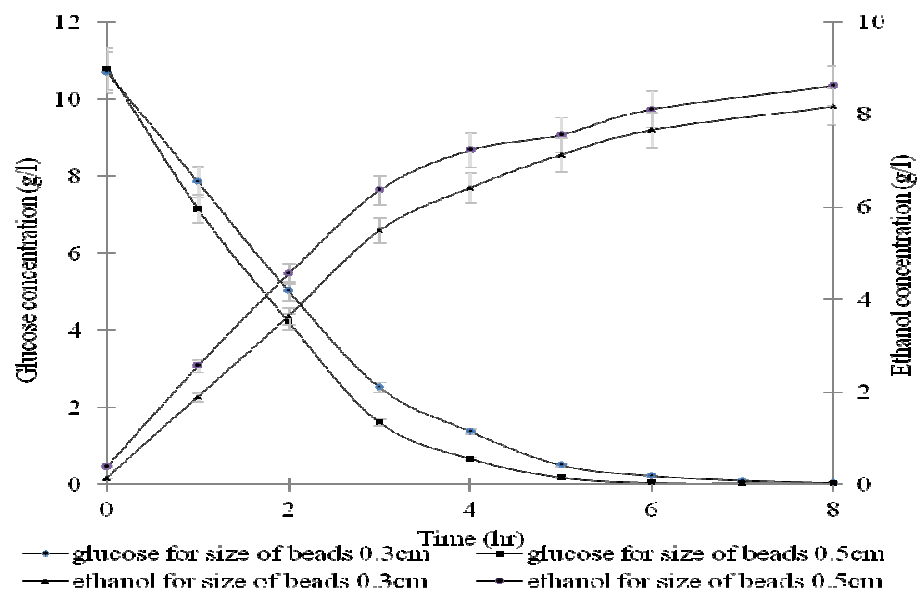

Fig. 2: Fermentations profile for two different size using $150 \mathrm{~g} / \mathrm{L} \mathrm{LBS}$. 


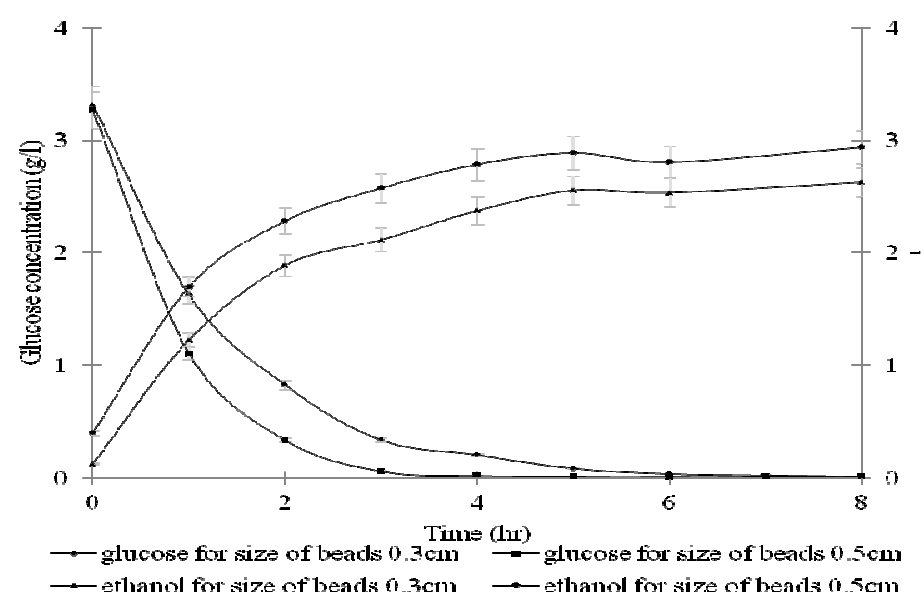

Fig. 3: Fermentations profile for two different size using $50 \mathrm{~g} / \mathrm{L} \mathrm{LBS.}$

\subsection{Effects of Ratio (Beads : Substrate)}

The amount of beads to the substrate was investigated using ratio of the volume of beads to the volume of the substrate to evaluate the effect of the surface-volume ratio beads to substrate for bioethanol production. The experiment was conducted in two chosen ratio; 0.2 and 0.6 where ratio 0.2 represented $30 \mathrm{ml}$ of beads in $150 \mathrm{ml} \mathrm{LBS}$ media and 0.6 represented $90 \mathrm{ml}$ of beads in $150 \mathrm{ml}$ LBS media. The graph in Fig. 4 and 5 showed the ethanol production was highest at ratio 0.6. This maybe due to the fact that the amount of beads used was higher than at ratio 0.2. More beads in a solution making large area for mass transfer resulted in better ethanol production.

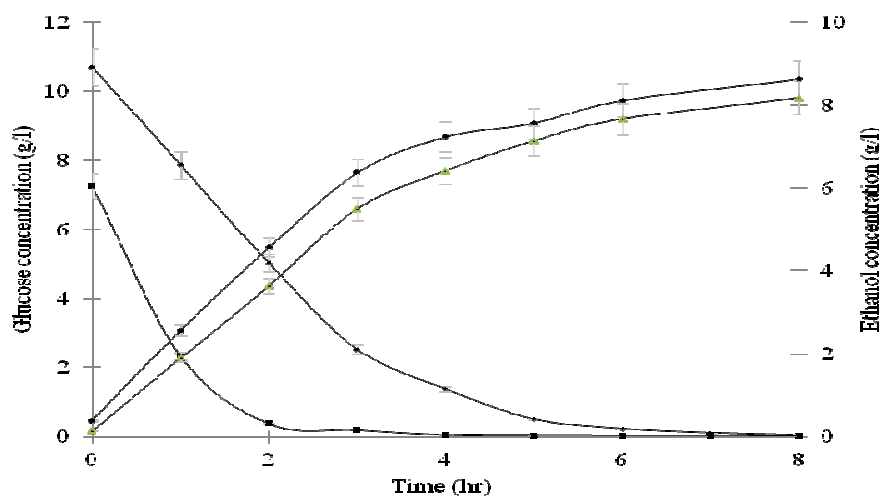

ghcose for ratio 0.2 (beads:aubetrate) $\rightarrow$ glucose for ratio 0.6 (beads Enlostrate: ethanol for ratio 0.2 (beads:aubatiate; $\rightarrow-$ ethanol for ratio 0.6 (beads: gubstrate)

Fig. 4: Fermentations profile for two different ratio size in $150 \mathrm{~g} / \mathrm{L} \mathrm{LBS}$. 


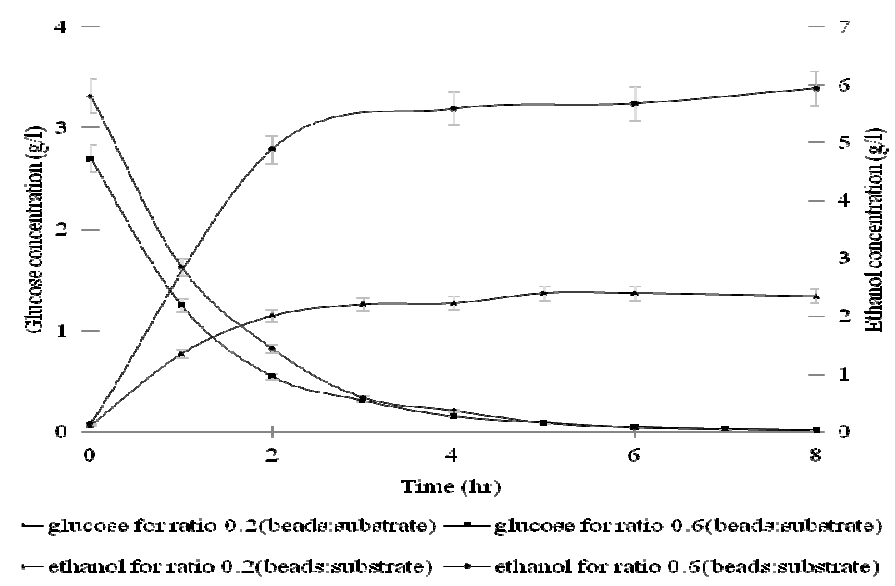

Fig. 5: Fermentations profile for two different size in $50 \mathrm{~g} / \mathrm{L} \mathrm{LBS.}$

\subsection{Effects of Concentration LBS}

The effect of concentration LBS on ethanol fermentation by immobilized ST1 strain was studied. Two concentrations of LBS, $50 \mathrm{~g} / \mathrm{L}$ and $150 \mathrm{~g} / \mathrm{L}$ were chosen, and the experiment was conducted in different size of beads $(0.3 \mathrm{~cm}$ and $0.5 \mathrm{~cm})$ and the results illustrated in Fig. 6 and 7. The glucose was consumed almost 99\% for both concentrations at $6^{\text {th }}$ hour fermentation. The maximum ethanol production were achieved using $150 \mathrm{~g} / \mathrm{L}$ LBS for both sizes of beads $(0.2$ and $0.6 \mathrm{~mm})$ at $8 \mathrm{~g} / \mathrm{L}$ and $8.2 \mathrm{~g} / \mathrm{L}$ respectively. Interestingly, glucose content in $50 \mathrm{~g} / \mathrm{L} \mathrm{LBS}$ and $\mathrm{g} / \mathrm{L}$ LBS when initially measured was in the range of 2.6-3 g/L and 7.8-10.7 g/L respectively. The theoretical yield [20] from the experiments were then calculated and showed in Fig 8. As expected, the higher the glucose concentrations, higher concentration of bioethanol being produced resulted in highest theoretical yield obtained $(67 \%)$.

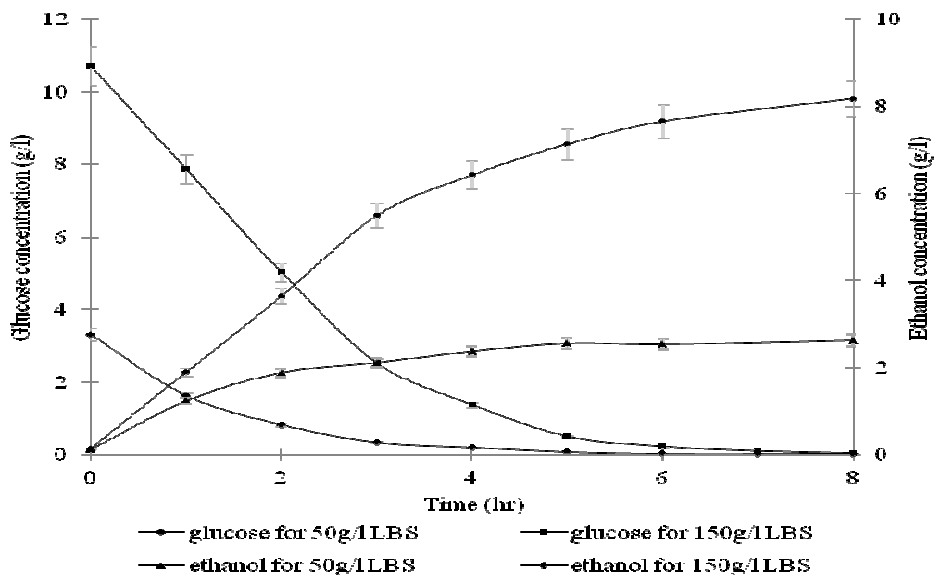

Fig. 6: Fermentations profile for concentration of $50 \mathrm{~g} / \mathrm{L}$ and $150 \mathrm{~g} / \mathrm{L} \mathrm{LBS}$ using $0.3 \mathrm{~cm}$ beads. 


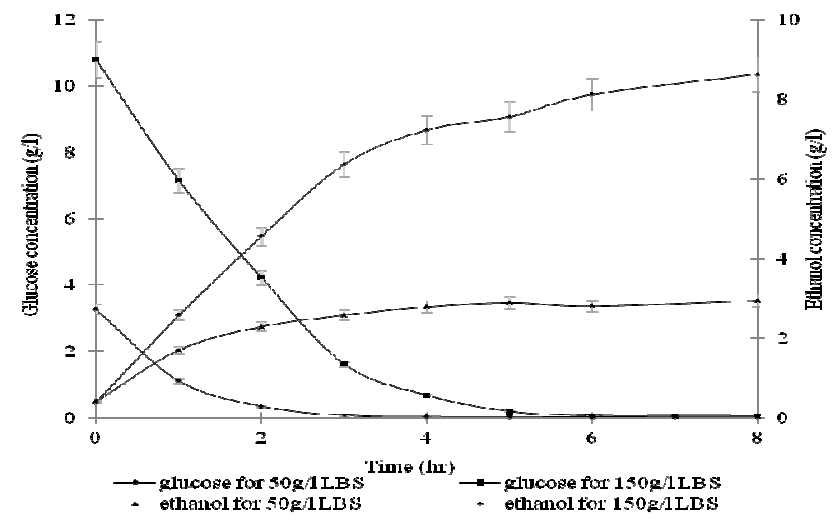

Fig. 7: Fermentations profile for concentration of $50 \mathrm{~g} / \mathrm{L}$ and $150 \mathrm{~g} / \mathrm{L} \mathrm{LBS}$ using $0.5 \mathrm{~cm}$ beads.

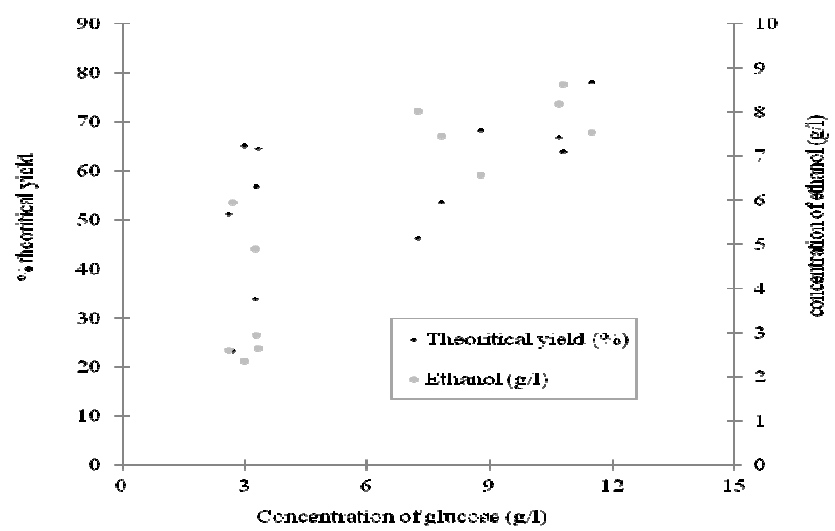

Fig. 8: Theoretical yield (\%) and maximum ethanol profile for overall parameters.

Table 1A and 1B showed the summary of overall fermentation profiles. The highest theoretical yield, $78 \%$ was obtained in ST1-alginate beads with the size of beads $0.5 \mathrm{~cm}$, ratio volume of beads to the volume of LBS media 0.4 and $150 \mathrm{~g} / \mathrm{L}$ concentration of LBS. The three variables parameter indicated that affected to the bioethanol production, but the alternative effect between these three parameters should not be neglected [21].

Table 1A: Summary of fermentation profile for all parameters.

\begin{tabular}{lcccccc}
\hline $\begin{array}{l}\text { Size of beads } \\
\text { Ratio (beads: } \\
\text { substrate) }\end{array}$ & \multicolumn{2}{c}{$0.3 \mathrm{~cm}$} \\
\hline $\begin{array}{l}\text { Concentration of } \\
\text { LBS (g/L) }\end{array}$ & 50 & 150 & 50 & 150 & 50 & 150 \\
Ethanol (g/L) & 2.63 & 8.18 & 2.35 & 6.58 & 5.94 & 8.02 \\
$\begin{array}{l}\text { Theoretical yield } \\
(\%)\end{array}$ & 65 & 67 & 65 & 68 & 23 & 46 \\
\hline
\end{tabular}


Table 1B: Summary of fermentation profile for all parameters.

\begin{tabular}{lcccccc}
\hline $\begin{array}{l}\text { Size of beads } \\
\text { Ratio (beads: }\end{array}$ & \multicolumn{7}{c}{$0.5 \mathrm{~cm}$} \\
substrate) & \multicolumn{2}{c}{0.2} & \multicolumn{2}{c}{0.4} & & 0.6 \\
\hline $\begin{array}{l}\text { Concentration of } \\
\text { LBS (g/L) }\end{array}$ & 50 & 150 & 50 & 150 & 50 & 150 \\
Ethanol (g/L) & 2.94 & 8.63 & 2.61 & 7.53 & 4.9 & 7.44 \\
$\begin{array}{l}\text { Theoretical yield } \\
(\%)\end{array}$ & 57 & 64 & 51 & 78 & 34 & 54 \\
\hline
\end{tabular}

\section{CONCLUSIONS}

It was concluded that higher ethanol production rates could be achieved by increasing concentration of LBS media and amount of beads in fermentation. However, the effect between three variables need to investigated further. The highest theoretical yield, $78 \%$ was obtained in ST1-alginate beads with the size of beads $0.5 \mathrm{~cm}$, ratio volume of beads to the volume of LBS media 0.4 and $150 \mathrm{~g} / \mathrm{L}$ concentration of LBS.

\section{ACKNOWLEDGEMENT}

The research is funded by University Research Grant (Code: UKM-GUP-BTT-07-25-165) which is duly acknowledged by authors.

\section{REFERENCES}

[1] S. Hiyasori, K. Jun, F. Yasuya, M. Takeshi, B. Yohei, U. Mitsuyosi, S. Eiichi, F. Hideki, and K. Akihiko, "Direct production of ethanol from raw corn starch via fermentation by use of a novel surface-engineered yeast strain codisplaying glucoamylase and $\alpha$-amylase," Applied and Environmental Microbiology, pp. 5037-5040, August 2004.

[2] B.V.V Ratnam, M. N. Rao, M. D. Rao, S.S. Rao, S.S. and C.Ayyana, "Optimization of fermentation conditions for the production of ethanol from sago starch using response surface methodology," World Journal of Microbiology \& Biotechnology, vol. 19, pp. 523526, 2003.

[3] H. Fukuda, A. Kondo, and S. Tamalampudi, " Bioenergy: Sustainable fuels from biomass by yeast and fungal whole-cell biocatalysts," Biochemical Engineering Journal, vol 44, pp. 212, 2009.

[4] S. Nikoloc, 1. Mojovic, D. Pejin, M. Rakin, and V. Vucuvic, " Improvement of Ethanol Fermentation of corn Semolina Hydrolyzates with Immobilized Yeast by Medium Supplementation" Food Technol. Biotechnol., vol 47, pp 83-89, 2009.

[5] M. Rakin, L. Mojovic, S. Nikolic, M. Vukasinovic, and V. Nedovic, "Bioethanol production by immobilized Sacharomyces cerevisiae var. ellipsoideus cells," African Journal of Biotechnology Vol.8(3):464-471, 2009.

[6] Margaritis, and P. M. Kilonzo, "Production of ethanol using immobilized cell bioreactor systems," Application of cell immolisation bioetechnology, vol. 8B, pp.375-401, 2005.

[7] M.A.A da Cunha, A. Converti, J.C. Santos, and Silva, S.S. "Yeast Immobilization in LentiKats : A New Strategy for Xylitol Bioproduction from Sugarcane Bagasse," World J. Microbiol. Biotechnol., vol.22(1), p : 65-72, 2006.

[8] R.L.C. Giordano, P.C. Hirano, L.R.B Goncalves, W.S. Netto, "Study of Biocatalyst to Produce Ethanol from Starch" applied Biochemistry and Biotechnology,pp 84-86, 2000. 
[9] R.A. Peinado, J.J Moreno, J.M. Vilalba, J.A.G. Reyes, J.M. Ortega, and J.C. Mauricio, "Yeast biocapsules: A new immobilization method and their applications," Enzyme and microbial Technology, vol. 40, pp.79-84, 2006.

[10] G. Najafpour, H. Younesi, and K. S. K. Ismail, "Ethanol Fermentation in an Immobilized Cell Reactor Using Saccharomyces cerevisiae,” Bioresource Technol., vol. 92, pp. 251-269, 2004.

[11] Y. Goksungur, and N. Zorlu, "Production of Ethanol from Beet Molasses by Ca-Alginate Immobilised Yeast Cells in a Packed-Bed Reactor," Turk J. Biol., vol.25, pp. 265-275, 2001.

[12] N.T.P Dung, F.M. Rombouts and M.J.R. Nout, "Characteristic of some traditional Vietnamese starch-based rice wine fermentation starters (men)," Food Science and Technology, vol. 40(1), pp. 130-135, 2007.

[13] I.N. Sujaya, S. Amachi, K. Saito, A. Yokota, K. Asano, and F. Tomita, "Specific enumeration of lactic acid bacteria in ragi tape by colony hybridization with specific oligonucleotide probes," World Journal of Microbiology \& Biotechnology, vol.18, pp. 263$270,2002$.

[14] K.H. Streinkraus, Indigenous fermented food in which ethanol is a major product. In Handbook of Indigenous Fermented Food, $2^{\text {nd }}$ ed.Steinkraus, K.H.:365-508. New York: Marcel Dekker, 1996.

[15] T. C. Cronk, K. H. Steinkraus, L. R. Hackler, and L.R. Mattick, "Indonesian Tape ketan Fermentation," Applied and environmental microbiology, pp. 1067-1073, 1977.

[16] C.S. Rathnasabapathy, S.M. Basha and R. Dhanasekar. Enhanced production of Glutathione from Candida utilis using Palm Jaggery. Int. J. ChemTech Res.,1(4): $1137-1144$.

[17] J. Yu, X. Zhang, and T. Tab, "Optimization of media conditions for the production of ethanol from sweet sorghum juice by immobilized Saccharomyces cerevisiae," Biomass and bioenergy, vol. 33, pp. 521-526, 2009.

[18] A.K. Rajvanshi, and N. Nimbkar. Sweet sorghum R and D at the Nimbkar Agricultural Research Institute (NARI). Proceedings of First European Seminar on Sorghum for Energy and Industry, Toulouse, France, 1-3, April 1996. pp: 356-362.

[19] A.P. Koehler, K.C. Chu, E.T.S Houang, and A.F.B. Cheng, "Simple, Reliable and Costeffective Yeast Identification Scheme for the Clinical Laboratory," J. of Clinical Microbiol., vol.37 (2), pp. 422-426, 1999.

[20] P. Bravo, and G. Gonzales, "Continuous Ethanol Fermentation by Immobilized Yeast Cells in a Fluidised-Bed Reactor,'J. Chem. Technol. Biotechnol., vol. 52, pp. 127-134, 1991.

[21] G. Dragone, D. P. Silva, and J.B.A. Silva, "Factors influencing ethanol production rates at high-gravity brewing" Swiss Society of Food Science and Technology, vol 37, pp 797-802, March 2004. 